Supplement of Web Ecol., 16, 17-31, 2016

http://www.web-ecol.net/16/17/2016/

doi:10.5194/we-16-17-2016-supplement

(C) Author(s) 2016. CC Attribution 3.0 License.

(c) (i)

Supplement of

\title{
Incorporating natural and human factors in habitat modelling and spatial prioritisation for the Lynx lynx martinoi
}

\author{
K. Laze and A. Gordon \\ Correspondence to: K. Laze (m1.laze@outlook.com)
}

The copyright of individual parts of the supplement might differ from the CC-BY 3.0 licence. 
Supplementary material

S0. Lynx data

S0.1 Brief description of the country cooperation for the lynx conservation

So.2 Study area

S0.3. Environmental and human data

S1. Criterion for selection of pseudo-absences

S2. List of predictor variables used for the lynx models

S3. Neighbourhood variables

S4. Results of the tests of spatial autocorrelation, Kruskall-Wallis test, Pearson test

S5. Spatial autocorrelation of dependent variable

S6. Models

S7. Summary of best logistic regression model and model selection estimators

S8. Summary of best models, the variables sign, statistically significance coefficients and their standard errors

S9. Summary of best three RSPF regression models, the best GLM model with randomly removed permanent (and permanent + temporal) occurrences and model selection estimators

S10. Response of lynx to neighbourhood habitat loss

S11. The estimated probability of occurrence of the lynx with combined permanent + temporal occurrences

S12. Priority locations for extending current protected areas for the lynx conservation with combined permanent + temporal occurrences

S13. Stable forests in the cross-border areas 


\section{S0. Lynx data}

Lynx data were collected before 1990 in Europe but not in all countries in the southern-eastern Europe (e.g., in socialist Albania). These data started to be collected between 1990 and 1995 and then in 2000. They (data) were collected for conservation plan development by the means of a "standardised questionnaire" that were compiled by wildlife experts to update the status report for the years between 1996 and 2001 and to compare the species data with the species data of previous surveys (between 1990 and 1995) (Arx et al. 2004). This was to assess species population for each country allowing comparison between them, following the standards of Species Information Services (SIS) for all countries in Europe (Arx et al. 2004) including the countries in Southern-eastern Europe (for conservation plan development). Lynx distribution data were described using raster maps of resolution $10 \mathrm{~km} \times 10 \mathrm{~km}$ for lynx; the records of resolution $10 \mathrm{~km} \times 10 \mathrm{~km}$ were classified as permanently occupied areas if more than 50 percent of a $100 \mathrm{~km}^{2}$ grid cell (meaning that lynx population density was estimated to be higher e.g., than 0.65 in a given cell of $100 \mathrm{~km}^{2}$ in Albania; estimated population density of the lynx was 2.06 in Macedonia; there were no lynx population estimations for Montenegro and Kosovo) were permanently occupied by lynx (Arx et al. 2004) . Areas with single confirmed records consisted of one or more direct observations, tracks or dead lynx in the latest year (Arx et al. 2004) (meaning that lynx population density was estimated to be e.g., less than 0.65 in Albania in a given cell of $100 \mathrm{~km}^{2}$ ). The lynx population was up to 25 lynx individuals covering an area of distribution of $3800 \mathrm{~km}^{2}$ in Albania, 35 lynx individuals covering an area of distribution of $1700 \mathrm{~km}^{2}$ in Macedonia, and about 30 lynx individuals (covering an area of distribution of $1000 \mathrm{~km}^{2}$ in Montenegro) in Montenegro and Kosovo (Arx et al. 2004).

Between July 2006 and June 2007, a baseline survey was conducted by two local NGOs namely, Protection and Preservation of Natural Environment (PPNEA) in Albania and Macedonian Ecological Society (MES) in Macedonia in collaboration with Swiss organisation, namely, Coordinated Research Projects for the Conservation and Management of Carnivores in Switzerland (KORA). This survey was used "to assess the distribution and relative abundance of lynx" and to assess the distribution of wild ungulates, lagomorphs and tetraonids (using the technique of face-to-face interview) with key-informants in the northern and eastern Albania and western Macedonia (Ivanov et al. 2008). The questionnaires composed of 50 questions that were asked to at least two randomly selected people for a village; all questions (50) were grouped into six sections as follows: 1) presences and distribution of large mammal species in the last five years, 2) conflicts between large carnivore species and humans as well as human attitude to species, 3) livestock husbandry and compensation about livestock loss caused by carnivores, 4) socio-economic aspects of the villages, 5) information about the interviewee and 6) general information about the village (Ivanov et al. 2008). The questionnaires focused on key-informants (hunters, game wardens, foresters, shepherds, livestock breeders, beekeepers, cafeteria or market owners). The sampling areas (village) covered a (potential) distribution area of the lynx using a grid map of $10 \mathrm{~km} \times 10 \mathrm{~km}$; at least one village in each cell was randomly selected to be visited resulting to approximately 880 interviews (320 interviews in 91 villages in Albania and 560 interviews in 154 villages in Macedonia) (Ivanov et al. 2008). A coordinate of the Universal Transverse Mercator System (UTM) coordinate system for each village was taken using GPS equipment. At the same time, several fieldtrips were conducted to potential lynx distribution areas searching for hard facts e.g., lynx snow tracks (Ivanov et al. 2008). 
The relative number of positive answers (concerning the presence of the lynx or of the lynx prey in a grid cell of $10 \mathrm{~km} \times 10 \mathrm{~km}$ ) for each grid cell of $10 \mathrm{~km} \times 10 \mathrm{~km}$ defined the lynx and prey occurrences as follows: if there were encountered more than $50 \%$ of positive answers (on hard facts like lynx tracks, stuffed lynx, prepared lynx pelts, man attacked by lynx, domestic animals attacked by lynx, observed more than one lynx or female with cubs in a grid cell of $10 \mathrm{~km} \times 10 \mathrm{~km}$ ), the authors indicated this grid cells of $10 \mathrm{~km} \times 10 \mathrm{~km}$ as "a good probable presence" of lynx or of lynx prey in that grid cell. If there were less than $50 \%$ of positive answers in a grid cell of $10 \mathrm{~km} \times$ $10 \mathrm{~km}$, this grid cell was "a possible presence of lynx or of lynx prey". If there encountered no positive answers of interviewees in a grid cell of $10 \mathrm{~km} \times 10 \mathrm{~km}$, this grid cell was indicated "no presence of lynx or of lynx prey" in that grid cell of $10 \mathrm{~km} \times 10 \mathrm{~km}$ (Ivanov et al. 2008).

\section{S0.1. Brief description of the country cooperation for the lynx conservation}

Foreign organisations namely German Federal Agency for Nature Conservation (BfN), Naturschutz in Europa (EURONATUR), KORA and domestic non-governmental organisation PPNEA in Albania and MES in Macedonia are well involved into lynx data collection (e.g., lynx survey between 2006 and 2007 for Balkan Lynx Recovery Program) and in species conservation inside protected areas (Schwaderer et al. 2008). A pilot project has applied an ecosystem approach in a forested and mountainous cross-border protected area of Albania (namely Shebenik-Jabllanicë National Park) with Macedonia (IUCN 2011). Also, Rrajca beech forest of ShebenikJabllanicë National Park is proposed to be nominated a UNESCO nature conservation area (www.ppnea.org). Scientific and local knowledge were put together in defining protected area components (e.g., wildlife, habitat in IUCN (2012)) and in the preparation of a protected area management plan.

The network of protected areas amongst countries (namely Albania, Bosnia and Herzegovina, Croatia, Kosovo, Macedonia, Montenegro, Serbia and Slovenia) has been supported by World Wide Fund for Nature (WWF) Dinaric Arc Parks (part of European Green Belt) regional project aiming to establish a network of protected areas in this region and also to strengthen the collaboration between countries (IUCN 2013).

\section{S0.2. Study area}

The study area has a total area of $83,166 \mathrm{~km}^{2}$ and consists of the countries Albania, the former Yugoslav Republic of Macedonia, Montenegro, and Kosovo (Fig. 1). This study area covers the current distribution of the lynx (Breitenmoser et al. 2008). The four countries in the study area have been under socialist regimes from the end of the Second World War until the early1990s. Macedonia, Montenegro, and Kosovo originally formed part of Yugoslavia, which split into seven countries due to conflict and political disputes. This resulted in Macedonia being created in 1991, Montenegro in 2006, and Kosovo in 2008.

In CORINE land cover 2006, the area consisted of 30 percent of broadleaved and mixed forests, 3.8 percent of pastureland, 9.6 percent of agriculture land and 1.1 percent of urban areas (European Environmental Agency 2011). Protected areas covered approximately 7 percent of the study area and the total human population in the study area was approximately 7.2 million (based on a 2011 population census in Albania, Kosovo and Montenegro, and population data from Macedonia from 2010) (State Statistical Office Macedonia 2010, Institute of Statistics Albania 2011, Statistical Office of Kosovo 2011, Statistical Office of Montenegro 2011). 


\section{S0.3. Environmental and human data}

Land cover data were derived from the Corine Land Cover 2006 raster data set (version 15), with a resolution of $100 \mathrm{~m}$ (European Environmental Agency 2011). The data included nine classes consisting of coniferous forest, broadleaved forest, mixed forest, transitional woodland-shrub land, agricultural land, natural vegetation, pastures, bare rocks, burnt areas, and discontinuous urban fabric.

Elevation and a terrain ruggedness index for the study area were derived from a digital elevation map (15 m resolution) provided by AsterGDEM, a product of METI and NASA (METI and NASA 2011). The boundaries of Albania and Kosovo, road networks, villages and protected areas for Albania and Kosovo were provided by Environmental Legislation and Planning Albania (ELPA), Institute for Nature Conservation in Albania, Kosovo Ministry of Agriculture, Forestry and Rural Development and Kosovo Environmental Protection Agency (during the data collection occurred in 2008). The network of major roads and protected areas for Macedonia and Montenegro was geo-referenced using Google Earth in 2011. We used the category of discontinued urban fabric that was extracted from the Corine Land Cover 2006 as village data for the Macedonia and Montenegro. Boundaries of Montenegro and the Macedonia were provided by ESRI (Environmental Systems Research Institute 2014).

Forest data were derived from satellite images of Landsat TM and ETM+ for 2000 and 2007, with resolution of $28.5 \mathrm{~m}$ and were provided by Stefan Suess (Suess 2010). Support vector machine (SVM) chain classification approach (Knorn et al. 2009) was used for analysing satellite images (1988), 2000 and 2007; SVMs represent a group of non-parametric algorithms (Huang et al. 2002), and it was considered as one of the more recent developments in the field of machine learning (Janz et al. 2007 cited in Suess 2010). The accuracy values of forest cover maps were above 93\% and kappa values above $85 \%$ (Suess 2010) (for more technical details on forest data see Laze (2014)). Forest areas (raster cells) in the forest cover maps were majority filtered using a $3 \times 3$ kernel to eliminate noise (areas with less than 7 raster cells of forest in the 9 -raster cell window were considered as nonforested areas (Kuemmerle et al. 2009)).

All data were projected to UTM Zone $34 \mathrm{~N}$, datum WGS84 and prepared in ArcGIS using Arcmap 9.3 (Environmental Systems Research Institute 2014) (see Appendix S1). All data including neighbourhood variables used in the lynx models were aggregated to $1 \mathrm{~km}$ resolution using Zonal statistics in ArcGIS (with the aggregated raster cells taking the mean value of the lower resolution raster cells).

\section{S1. Criterion for selection of pseudo-absences}

We selected random coordinates of pseudo-absence locations from the entire study area using Hawth's Tools extension in ArcGIS 9.3 to run the analysis of occurrence and pseudo-absence model. The pseudo-absence selection had to fulfil three conditions as follows: (1) the number of absences were as same as the number of (permanent and temporal) occurrences per species, (2) only one location was selected from a given grid cell of 1 $\mathrm{km} \times 1 \mathrm{~km}$ and (3) absences were to be located in the forest areas and preferably within the species-specific habitats because generating pseudo-absences further away from the optimum established by the real presence data may increase over-prediction of the model (Chefaoui and Lobo 2008). 
S2. List of predictor variables used for the lynx models

\begin{tabular}{|c|c|c|}
\hline Definition of the variables & Units & Models \\
\hline \multicolumn{3}{|l|}{ Land cover 2006} \\
\hline Coniferous forest* ${ }^{*}$ & Percentage, $\mathrm{km}^{2}$ & 1 \\
\hline Broadleaved forest ${ }^{*}$ & Percentage, $\mathrm{km}^{2}$ & 1 \\
\hline Mixed forest ${ }^{*}$ & Percentage, $\mathrm{km}^{2}$ & 1 \\
\hline $\begin{array}{l}\text { Agricultural land with } \\
\text { natural vegnificant } \\
\text { agriculture land) }\end{array}$ & Percentage, $\mathrm{km}^{2}$ & 2 \\
\hline Bare rocks ${ }^{*}$ & Percentage, $\mathrm{km}^{2}$ & 1 \\
\hline $\begin{array}{l}\text { Discontinuous urban } \text { fabric }^{*} \\
\text { (thereafter urban land) }\end{array}$ & Percentage, $\mathrm{km}^{2}$ & 2 \\
\hline Burnt land* & Percentage, $\mathrm{km}^{2}$ & 2 \\
\hline Pastures $^{*}$ (thereafter pastureland) & Percentage, $\mathrm{km}^{2}$ & 1 \\
\hline $\begin{array}{l}\text { Transitional woodland-shrub land* } \\
\text { (thereafter transitional land) }\end{array}$ & Percentage, $\mathrm{km}^{2}$ & 1 \\
\hline \multicolumn{3}{|l|}{ Forest cover } \\
\hline Forest cover 2000 connectivity* & Percentage, $\mathrm{km}^{2}$ & 1 \\
\hline Forest cover 2007 connectivity* & Percentage, $\mathrm{km}^{2}$ & 1 \\
\hline \multicolumn{3}{|l|}{ Natural environment } \\
\hline Elevation & Meters per $\mathrm{km}^{2}$ & 1 \\
\hline Terrain ruggedness index ${ }^{*}$ & $\mathrm{~km}^{2}$ & 1 \\
\hline Prey presences & & 1 \\
\hline \multicolumn{3}{|l|}{ Anthropogenic variables } \\
\hline Euclidean distance to main road & Meters per $\mathrm{km}^{2}$ & 2 \\
\hline $\begin{array}{l}\text { Euclidean distance to human } \\
\text { settlement (thereafter distance to } \\
\text { populated areas) }\end{array}$ & Meters per $\mathrm{km}^{2}$ & 2 \\
\hline Euclidean distance to urban land & Meters per $\mathrm{km}^{2}$ & 2 \\
\hline Village density & Number of villages per $\mathrm{km}^{2}$ & 2 \\
\hline Road neighbourhood* & $\mathrm{km}^{2}$ & 2 \\
\hline Village neighbourhood* & $\mathrm{km}^{2}$ & 2 \\
\hline
\end{tabular}

Note: * Denotes the 14 spatial layers that had neighbourhood variables are given in units of coverage per $\mathrm{km}^{2}$. Model 1 is composed of natural variables. Model 2 is composed of anthropological variables.

\section{S3. Neighbourhood variables}

Our environmental variables are not necessarily related to the spatial scales at which our study species perceive the landscape and at which resources need to be available. Therefore, the data were transformed into a set of 
neighbourhood variables (Schadt et al. 2002, Naves et al. 2003, Wiegand et al. 2008, Kanagaraj et al. 2011). A neighbourhood variable was the mean value of the original variable within a specified neighbourhood radius around the target cell. For lynx, we used 7 different radii $(1,2,3,4,5,10$ and $15 \mathrm{~km})$ representing areas of 3.1 $\mathrm{km}^{2}, 28.3 \mathrm{~km}^{2}, 50.2 \mathrm{~km}^{2}, 78.5 \mathrm{~km}^{2}, 314 \mathrm{~km}^{2}$, and $706.5 \mathrm{~km}^{2}$ to define the scale of the distribution of the lynx.

\section{S4. Results of the tests of spatial autocorrelation, Kruskall-Wallis test, Pearson test}

The dependent variable showed insignificant spatial autocorrelation value because Moran's I value was p-value $<0.001$ for combined permanent + temporal occurrences.

The variables that passed the Kruskal-Wallis test for permanent occurrences were elevation, chamois, pasture neighbourhood of $1 \mathrm{~km}$, terrain index neighbourhood from $2 \mathrm{~km}$ to $15 \mathrm{~km}$, transitional land neighbourhood of 2 $\mathrm{km}, 4 \mathrm{~km}, 5 \mathrm{~km}, 10 \mathrm{~km}$, broadleaved forests neighbourhood of $10 \mathrm{~km}$, agricultural land from $4 \mathrm{~km}$ to $15 \mathrm{~km}$ and village neighbourhood of $4 \mathrm{~km}$.

The variables that passed the Kruskal-Wallis test for combined permanent + temporal occurrences were as follows: broadleaved forest, agriculture land, urban land, Euclidean distance to human settlement, Euclidean distance to urban land, village density, brown hare, roe deer occurrences and chamois occurrences, forest cover in percentage and forest cover neighbourhood, elevation, terrain index neighbourhood; mixed forest neighbourhood $10 \mathrm{~km}, 15 \mathrm{~km}$, broadleaved forests neighbourhood from $1 \mathrm{~km}$ to $15 \mathrm{~km}$, agriculture land neighbourhood from $1 \mathrm{~km}$ to $15 \mathrm{~km}$, pastureland neighbourhood from $1 \mathrm{~km}$ to $15 \mathrm{~km}$, urban land neighbourhood $1 \mathrm{~km}, 3 \mathrm{~km}, 4 \mathrm{~km}, 5 \mathrm{~km}, 10 \mathrm{~km}, 15 \mathrm{~km}$, village neighbourhood 2 km, 3 km, 4 km. Prey occurrences, forest cover and neighbourhood forest cover of $12.56 \mathrm{~km}^{2}, 28.26 \mathrm{~km}^{2}, 50.24 \mathrm{~km}^{2}$ were correlated (Pearson correlation; $r>$ 0.70). The performance of model was checked with these variables (the variable was considered in the model that obtained the lowest value of AICc).

\section{S5. Spatial autocorrelation of dependent variable}

Spatial autocorrelation of dependent variables was checked in Geoda095i to ensure non-biased results (Naves et al. 2003). In short, a spatial weights matrix was created, using the first order queen's contiguity neighbour; the first order neighbours had weights. If spatial autocorrelation was high, then we needed to use sample of observations and repeat the test of spatial autocorrelation until the spatial autocorrelation was insignificant of the sample of observations. Spatial autocorrelation of one $\mathrm{km}$ grain showed a non-significant value for the dependent variable of p-value < 0.001 (see e.g. May et al. 2008).

\section{S6. Models}

\section{Model one (natural variable candidate models)}

The hypothesis was based on the literature on lynx, and knowledge of its biology and ecology. The lynx needs an adequate area of forests and land that provide suitable habitats for refuge, breed and food. The candidate model included elevation, forest cover, and terrain index neighbourhood variable because lynx required dense, high, 
undisturbed forests and high topography to refuge, breed and search for food (Kramer-Schadt et al. 2005, Fernández et al. 2006). This model included occurrences of prey, forest connectivity and land cover categories. Land cover categories consisted of coniferous forest, broadleaved forest, mixed forest, pastureland, and transitional land, and bare rocks (Appendix S1). Prey occurrences and pastureland determined the occurrences (presences) of the lynx for food, while forests and bare rocks for refuge and breeding (Fernández et al. 2003, Balkan Lynx Strategy Group 2008).

\section{Model two (human disturbance candidate models)}

Human explanatory variables consisted of the Euclidean distance to urban land, Euclidean distance to road, density of road, village density, agriculture land, urban land. We produced two types of these models. Village locations and their diffusion disturbed the specie habitats (see Naves et al. 2003). Roads were assumed to affect negatively the specie (occurrences) presences (see Kramer-Schadt et al. 2005). These two variables were employed in the first model two. In the second model composed of human disturbance variables, we used urban land that was available for the entire study area. The Euclidean distance to urban land was added in this model to check if this variable was statistically significant to the occurrences of the lynx.

S7. Summary of best logistic regression models and model selection estimators. Neighbourhood area is the scale (see Methods); AICc = corrected Akaike's Information Criterion; $\triangle \mathrm{AICc}=$ difference of corrected Akaike's Information Criterion; Akaike wi $=$ Akaike weight; $\mathrm{D}^{\wedge} 2=$ Deviance Explained; $\mathrm{CV}=$ cross validation; $\mathrm{AUC}=$ area under curve $i$.

\begin{tabular}{|c|c|c|c|c|c|c|c|}
\hline $\begin{array}{c}\text { Lynx } \\
\text { occurrences }\end{array}$ & Models & $\begin{array}{c}\text { Neighbourhood } \\
\text { area }(\mathrm{km} 2)\end{array}$ & $\mathrm{AICc}$ & $\triangle \mathrm{AICc}$ & $\begin{array}{c}\mathrm{AUC}, \\
(\%)\end{array}$ & $\begin{array}{l}\mathrm{D}^{\wedge} 2, \\
(\%)\end{array}$ & $\begin{array}{l}\mathrm{CV}, \\
(\%)\end{array}$ \\
\hline \multirow{7}{*}{ Permanent } & NM1: & & & & & & \\
\hline & $\begin{array}{l}\text { ELEV, TRIR, } \\
\text { CHP, TRANP }\end{array}$ & 50.2 & 88.5 & 0.0 & 82.6 & 16.7 & 71.8 \\
\hline & NM2: & & & & & & \\
\hline & $\begin{array}{l}\text { ELEV, TRIR, } \\
\text { CHP, TRANP }\end{array}$ & 78.5 & 89.8 & 1.3 & 82.3 & 15.4 & 69.2 \\
\hline & NM3: & & & & & & \\
\hline & $\begin{array}{l}\text { ELEV, CHP, } \\
\text { PASRP }\end{array}$ & 3.1 & 92.0 & 3.5 & 78.8 & 11.6 & 73.1 \\
\hline & $\begin{array}{l}\text { HM: } \\
\text { AGLRP }\end{array}$ & 314 & 104.6 & 16.1 & 65.2 & -0.27 & 56. \\
\hline
\end{tabular}




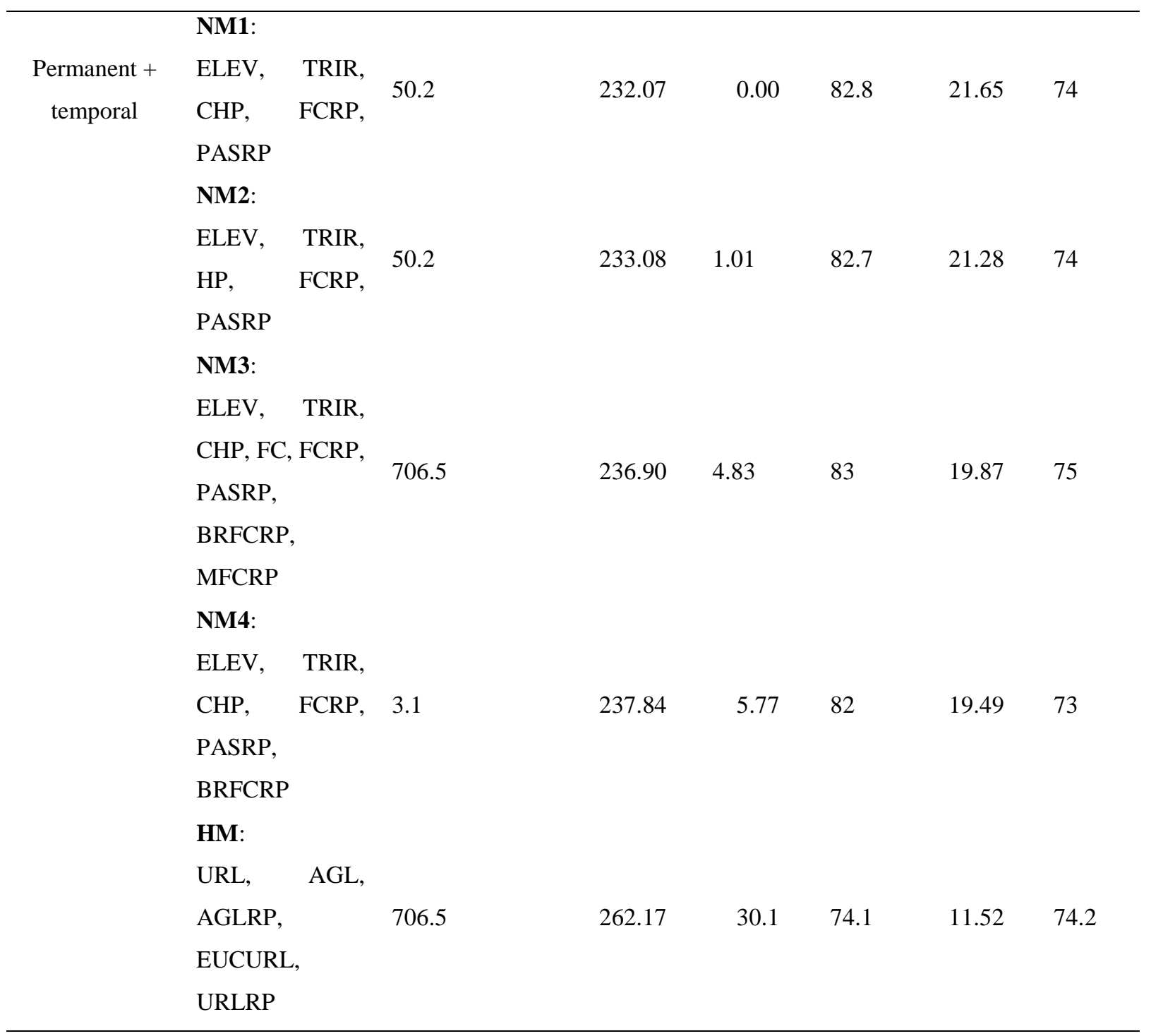

Note: Model one (NM1) is the parsimonious model (the best model from all natural variable and human disturbance candidate models) of the lynx. Models (NM1, NM2, NM3) for lynx permanent occurrences and models (NM1, NM2, NM3, NM4) for lynx combined permanent + temporal occurrences are used for the calculation of the BQP curve and Zonation analysis. Model two (HM) is the best model from all human disturbance candidate models. ELEV is the elevation, TRIR is terrain ruggedness index neighbourhood, CHP is the chamois occurrences, TRANP is transitional land, FCRP is the forest cover neighbourhood in percentage, PASRP is the of pastureland neighbourhood in percentage, HP is brown hare occurrences, BRFCRP is broadleaved forest neighbourhood, FC is forest cover in percentage, MFCRP is mixed forest neighbourhood, URL is urban land in percentage, AGL is agriculture land in percentage, AGLRP is agriculture land neighbourhood, EUCURL is Euclidean distance to urban land, URLRP is urban land neighbourhood. 
S8. Summary of best models of lynx permanent occurrences and permanent + temporal occurrences, the variables sign, statistically significance coefficients and their standard errors

\begin{tabular}{|c|c|c|c|c|c|c|c|c|}
\hline $\begin{array}{l}\text { Lynx } \\
\text { occurrences }\end{array}$ & Model & $\begin{array}{l}\text { Neighbourhood } \\
\text { area }\left(\mathrm{km}^{2}\right)\end{array}$ & AICc & Variables & Coefficients & $\begin{array}{l}\text { Standard } \\
\text { errors of } \\
\text { coefficients }\end{array}$ & Sign & $\begin{array}{l}p \text { - } \\
\text { value }\end{array}$ \\
\hline \multirow[t]{16}{*}{ Permanent } & NM1 & 50.2 & 88.5 & ELEV & 0.0018 & 0.0006 & + & 0.006 \\
\hline & & & & TRIR & 0.007 & 0.044 & + & 0.866 \\
\hline & & & & CHP & 2.293 & 1.620 & + & 0.156 \\
\hline & & & & TRANP & 935.9 & 356.1 & - & 0.008 \\
\hline & & & & Intercept & 1.383 & 1.256 & - & 0.271 \\
\hline & NM2 & 78.5 & 89.8 & ELEV & 0.0016 & 0.0006 & + & 0.012 \\
\hline & & & & TRIR & 0.0305 & 0.0502 & + & 0.54 \\
\hline & & & & CHP & 2.300 & 1.626 & + & 0.15 \\
\hline & & & & TRANP & 884.4 & 362.3 & - & 0.014 \\
\hline & & & & Intercept & 1.843 & 1.348 & - & 0.171 \\
\hline & NM3 & 3.14 & 93.7 & ELEV & 0.0016 & 0.0005 & + & 0.003 \\
\hline & & & & CHP & 2.411 & 1.647 & + & 0.143 \\
\hline & & & & PASRP & 136.1 & 173.9 & - & 0.433 \\
\hline & & & & Intercept & 1.985 & 0.719 & - & 0.005 \\
\hline & $\mathrm{HM}$ & 314 & 104.6 & AGLRP & 832.5 & 336.8 & - & 0.013 \\
\hline & & & & Intercept & 0.740 & 0.376 & + & 0.049 \\
\hline \multirow{16}{*}{$\begin{array}{l}\text { Permanent } \\
+ \text { temporal }\end{array}$} & NM1 & 50.2 & 232.07 & ELEV & 0.002 & 0.000 & + & 0.000 \\
\hline & & & & TRIR & 0.010 & 0.024 & - & 0.688 \\
\hline & & & & CHP & 3.346 & 1.524 & + & 0.028 \\
\hline & & & & FCRP & 807.4 & 193.6 & + & 0.000 \\
\hline & & & & PASRP & 24.92 & 85.10 & + & 0.769 \\
\hline & & & & Intercept & 2.925 & 0.723 & - & 0.000 \\
\hline & NM2 & 50.2 & 233.08 & ELEV & 0.002 & 0.000 & + & 0.000 \\
\hline & & & & TRIR & 0.010 & 0.024 & - & 0.677 \\
\hline & & & & HP & 3.240 & 1.519 & + & 0.032 \\
\hline & & & & FCRP & 805.9 & 193.1 & + & 0.000 \\
\hline & & & & PASRP & 25.88 & 84.44 & + & 0.759 \\
\hline & & & & Intercept & 2.875 & 0.717 & - & 0.000 \\
\hline & $\mathrm{HM}$ & 706.5 & 262.17 & URL & 0.093 & 0.061 & - & 0.128 \\
\hline & & & & EUCURL & 0.000 & 0.000 & + & 0.576 \\
\hline & & & & AGL & 0.008 & 0.009 & - & 0.397 \\
\hline & & & & AGLRP & 1469 & 315.1 & - & 0.000 \\
\hline
\end{tabular}




\begin{tabular}{lllll} 
URLRP & 208.1 & 123.9 & - & 0.093 \\
Intercept & 1.659 & 0.396 & + & 0.000 \\
\hline
\end{tabular}

Note: Model one (NM) is composed of natural variables. The number 1, 2, 3 shows the best models one composed of natural variables. Model two (HM) is the best model from all human disturbance candidate models. ELEV is the elevation, TRIR is terrain ruggedness index neighbourhood, CHP is the chamois occurrences, FCRP is the forest cover neighbourhood in percentage, PASRP is the of pastureland neighbourhood in percentage, HP is brown hare occurrences, BRFCRP is broadleaved forest neighbourhood, FC is forest cover in percentage, MFCRP is mixed forest neighbourhood, URL is urban land in percentage, AGL is agriculture land in percentage, AGLRP is agriculture land neighbourhood, EUCURL is Euclidean distance to urban land, URLRP is urban land neighbourhood.

S9. Summary of best three RSPF regression models and the best GLM model with randomly removed permanent occurrences and with randomly removed combined permanent + temporal occurrences and model selection estimators. Neighbourhood area is the scale (see Methods); Log-likelihood =Maximum Likelihood estimates with Nonparametric Bootstrap standard errors (B =99), BIC = Bayesian Information criteria, $\mathrm{AIC}=$ Akaike's Information Criterion; $\chi^{2}=$ chi-squared test statistic, $\mathrm{p}$-value $=$ model statistically significance, $\mathrm{AICc}=$ corrected Akaike's Information Criterion; $\triangle \mathrm{AICc}=$ difference of corrected Akaike's Information Criterion (the best GLM models are NM1P and NM1 in Appendix S8); D^2 = Deviance Explained; CV = cross validation; AUC = area under curve $i$.

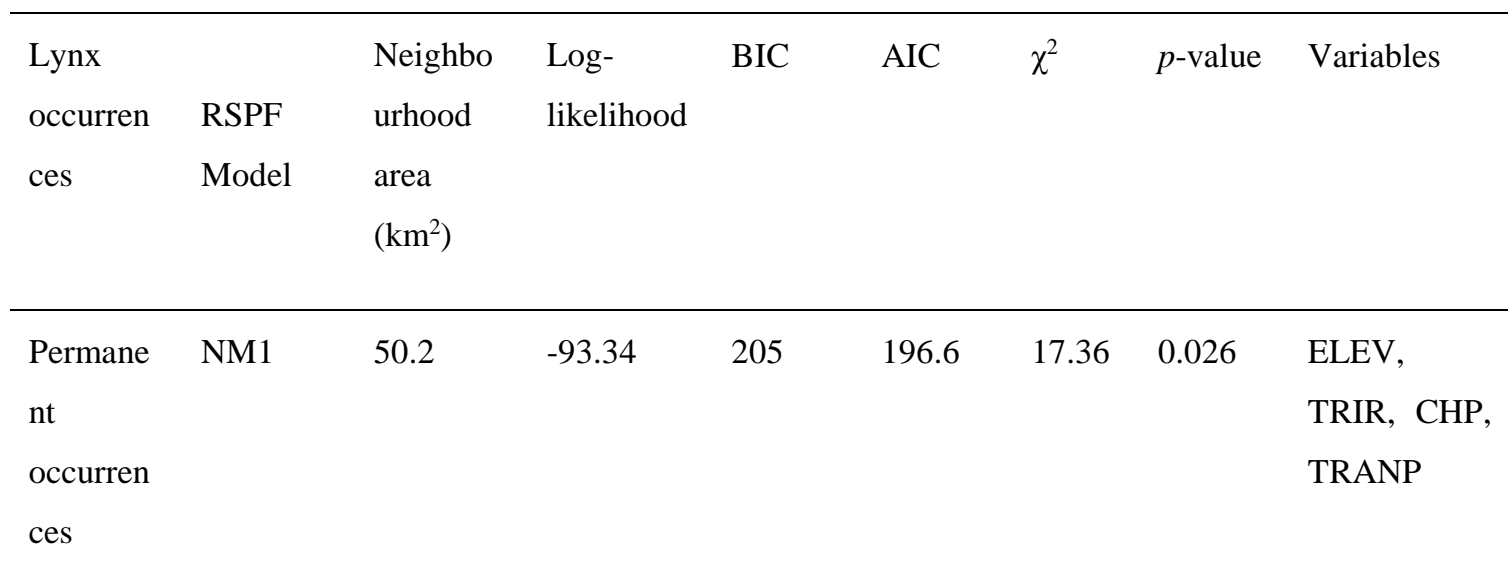

\begin{tabular}{|c|c|c|c|c|c|c|c|}
\hline NM2 & 78.5 & -93.2 & 204.7 & 196.4 & 14.63 & 0.066 & $\begin{array}{l}\text { ELEV, } \\
\text { TRIR, CHP, } \\
\text { TRANP }\end{array}$ \\
\hline NM3 & 314 & -92.56 & 207.1 & 197.1 & 27.98 & 0.0004 & $\begin{array}{l}\text { ELEV, } \\
\text { TRIR, CHP, } \\
\text { TRANP, } \\
\text { BRFCRP }\end{array}$ \\
\hline
\end{tabular}




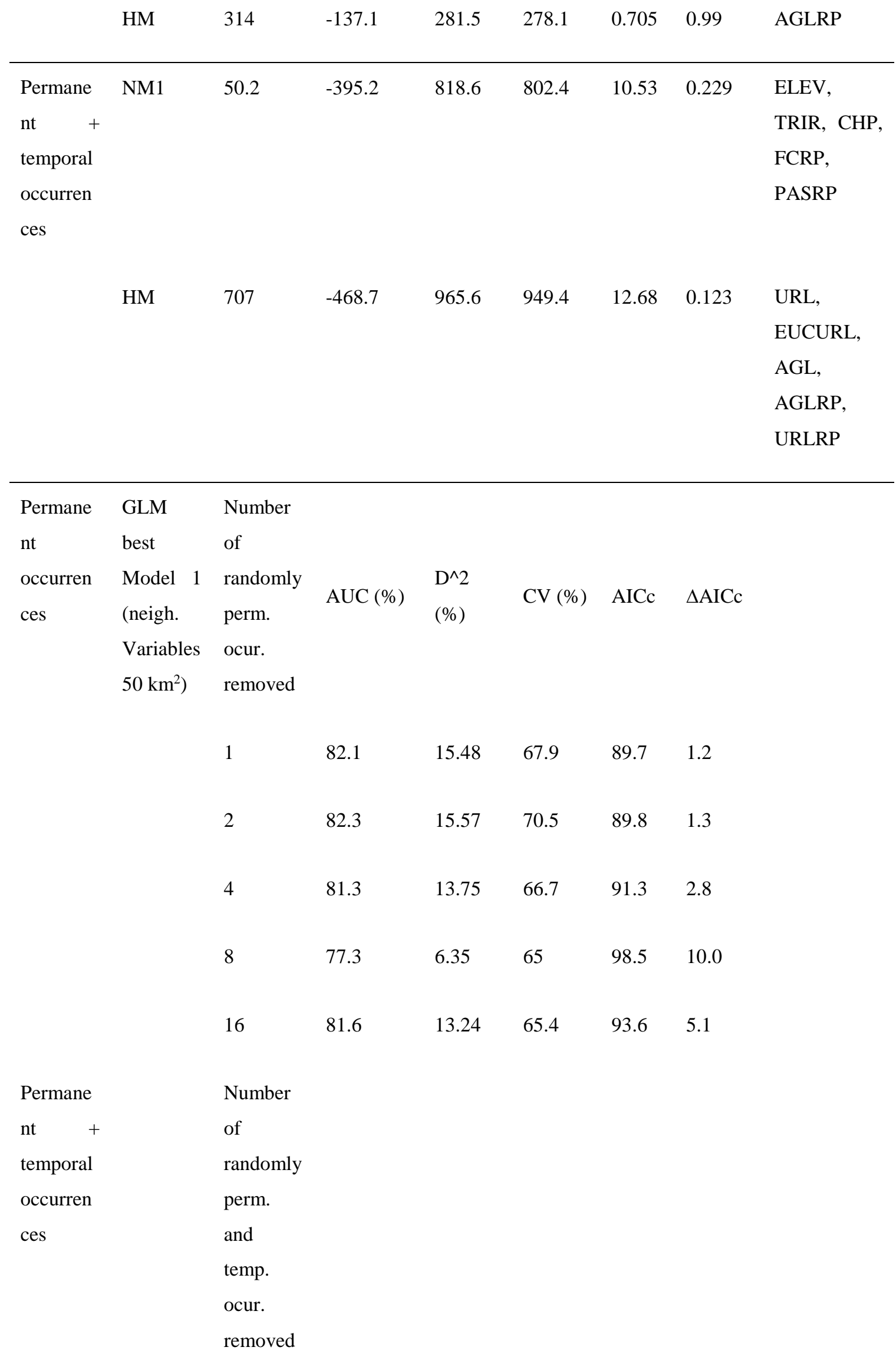




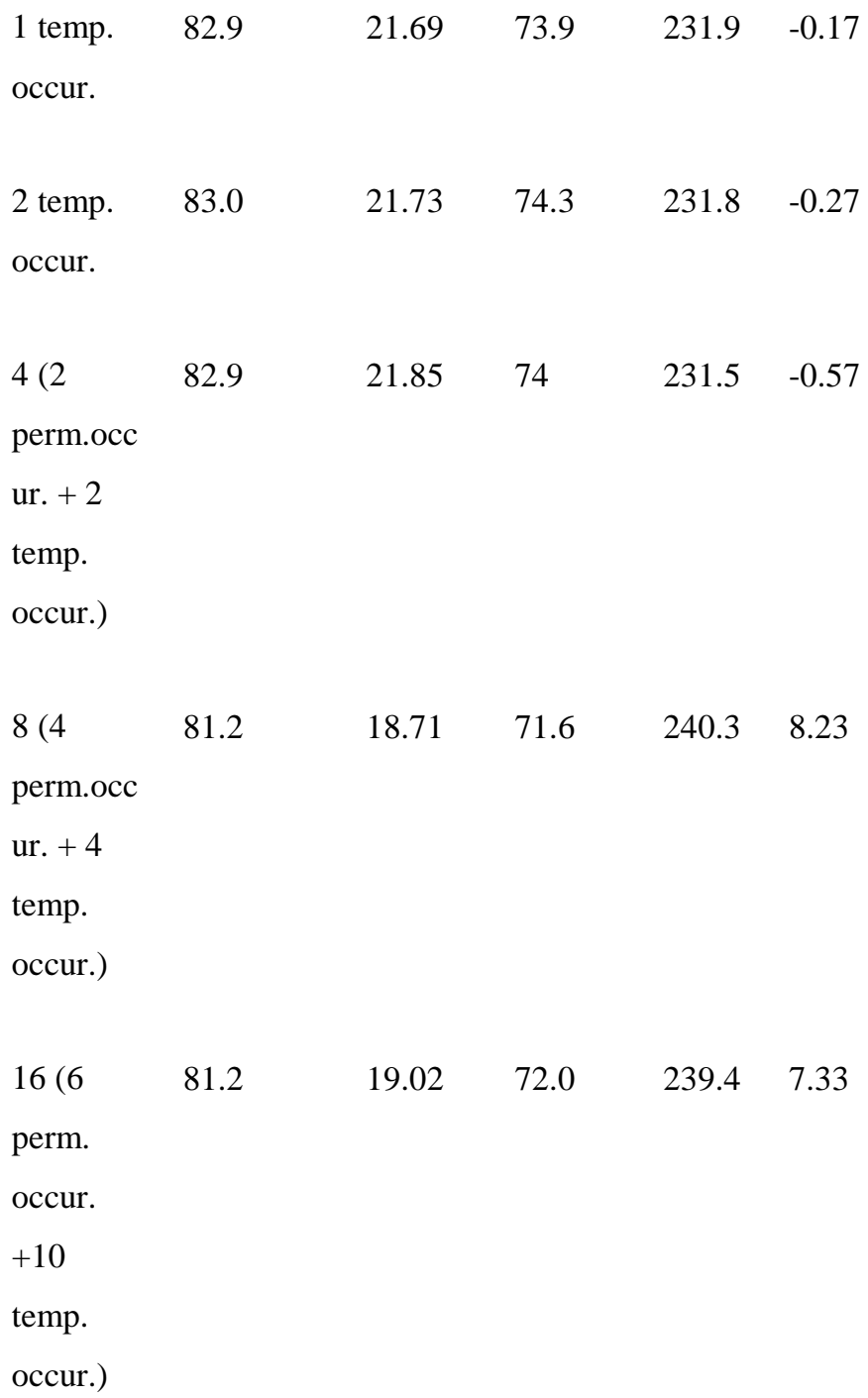

Note: Model one (NM) is composed of natural variables. The number 1, 2, 3 shows the best models one composed of natural variables. Model two (HM) is the best model from all human disturbance candidate models. 
Figure S9. Estimated probability of occurrence of the lynx by the best RSPF model. Model 1 with range of neighbourhood variables of $50.2 \mathrm{~km}^{2}$ is in Table of Appendix S9.

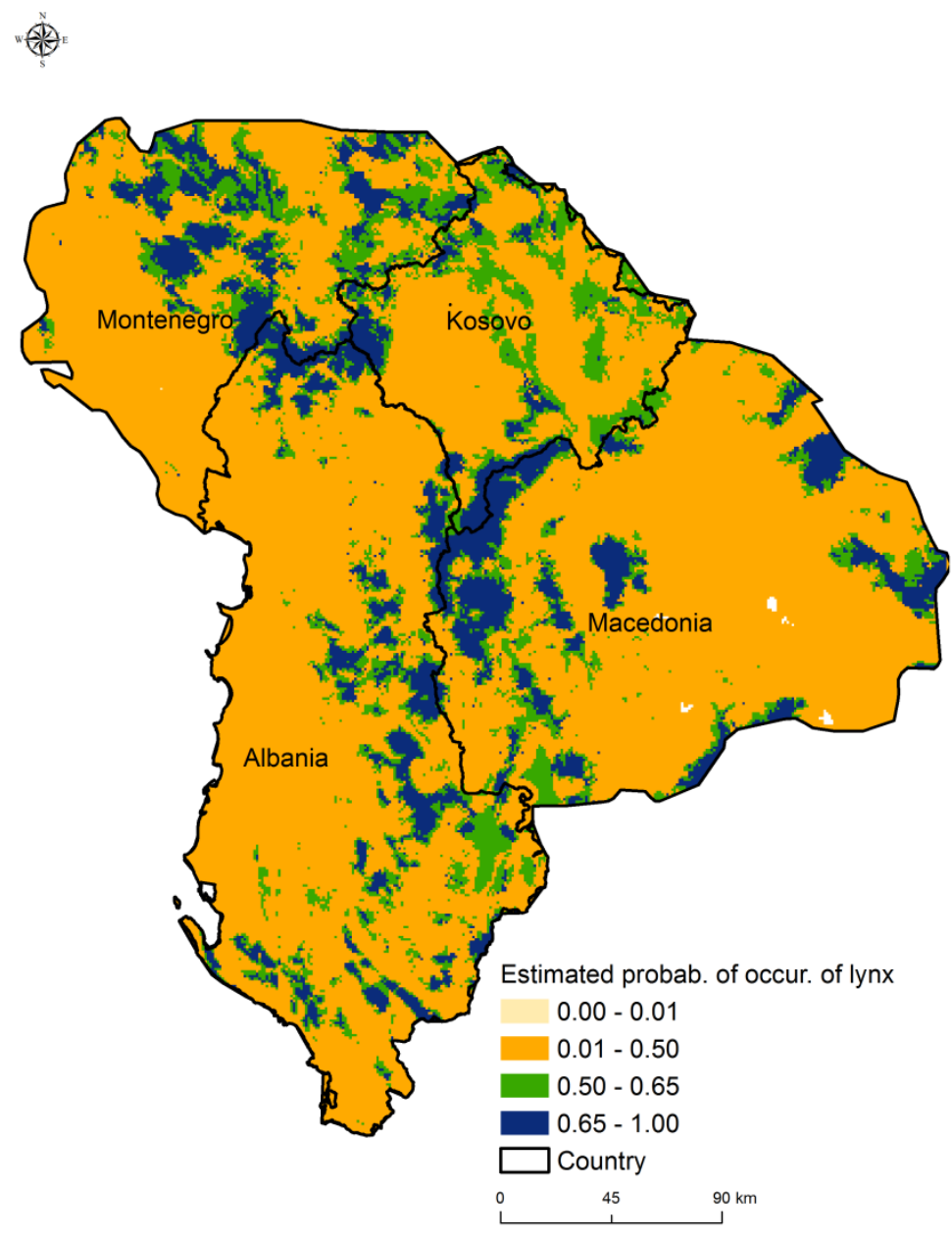

\section{S10. Response of the lynx to neighbourhood habitat loss}

Three best models with the range of $50.24 \mathrm{~km}^{2}, 706.5 \mathrm{~km}^{2}$, and $3.14 \mathrm{~km}^{2}$ (Appendix S7, S8) were used to calculate the BQP curve. Marine protected areas of Albania and marine protected areas of the cross-border Albania and Montenegro were excluded from the analysis. These protected areas had no occurrences of the lynx and were not designed for the protection of the lynx. The terrestrial protected areas were used as removal mask to identify those cells that were processed by Zonation. Cell removal rule was applied. The model one layer of the lynx was used as the biodiversity and condition file in Zonation software.

Retention layers were four and were prepared as follows: 1- this retention layer considered a slight change of protected areas assuming a loss of habitat suitability inside of protected areas, 2-this retention layer assumed that the condition of habitat suitability within protected areas had improved by $30 \%$ because of the management interventions of the protected area management institutions (these management measures were supposed to increase the protection of landscape within protected areas), 3-retention layer three also assumed that the condition of habitat suitability had increased by $30 \%$ because of managerial interventions of the institutions of protected areas. Here, this retention layer (i.e., three) included the cells of habitat suitability with probability values from 
0.75 to 1.00 .4 - This retention layer assumed no protection for the entire suitable habitat of lynx. In the end, the existing network of the protected areas was overlapped with the results of Zonation to identify the new areas for the expansion of existing protected areas for lynx.

The BQP curve was calculated from the species distribution modelling using three natural variables models NM1, NM2, NM3 for lynx permanent occurrences and NM1, NM2, NM3 for lynx permanent + temporal occurrences (Appendix S7). This was new way of calculation of the response of lynx to the fragmentation of landscape. The curve of BQP was strong, showing that lynx was sensitive to the fragmentation of habitat, Figure S10.

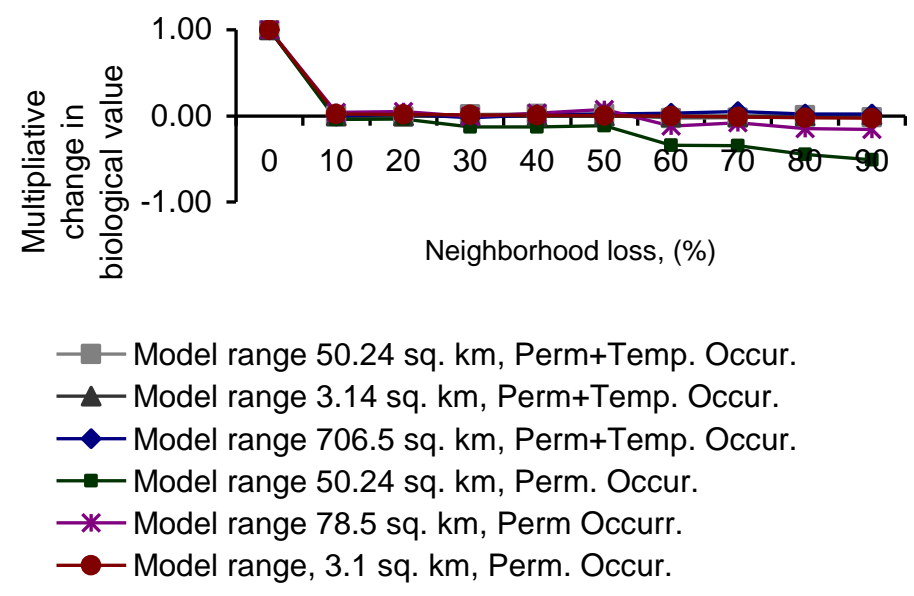

Figure S10. Three responses of lynx to habitat loss in surrounding cells for three models of lynx with Chamois prey occurrences (Appendix S7, S8). The x-axis shows the percent of habitat loss from the neighbourhood surrounding the focal cell of radius e.g., of $4 \mathrm{~km}$ (or range of $50.24 \mathrm{~km}^{2}$ ), radius of $1 \mathrm{~km}$ or range of $3.14 \mathrm{~km}^{2}$ and radius of $15 \mathrm{~km}$ or range of $706.5 \mathrm{~km}^{2}$ for permanent + temporal occurrences. The y-axis shows the loss in high values of estimated probability of lynx occurrences (habitat suitability) of the focal cells.

Figure S10 showed that lynx reacted to the fragmentation of the areas with high probability of lynx occurrences. Kramer-Schadt et al. (2004) studied the connectivity of patches of suitable habitats (estimated high probability of lynx occurrences in our study) and the division of habitats (into smaller habitats or into smaller areas with estimated high probability of lynx occurrences) for Eurasian lynx showing that the connectivity of patches of suitable habitat was possible by the "movements of dispersing lynx", however, most of patches could be isolated because of the road mortality of Eurasian lynx. Kramer-Schadt et al. (2005) showed also that "low probability of connectivity between suitable patches" jeopardized efforts to re-introduce Eurasian lynx in the fragmented landscape of Germany.

S11. The estimated probability of occurrence of the lynx with permanent + temporal occurrences (a) in the cross-border area of Montenegro, Albania and Kosovo, (b) in the cross border area of Albania, Macedonia and Kosovo (c) model one (biological feature used in Zonation), (d) model two (cost layer used inverted in Zonation) and existing terrestrial protected areas. The numbers (1), (2), (3), (4), (5), (6) identifies approximately areas of the lynx photos captured in Kosovo (in year 2015), 27 and 21 photos in Albania (in year 2014 and in winter time between 2014 and 2015, respectively) and 37 photos in (5) (in year 2015) and in (6) (in year 2013) in Macedonia, 
respectively. These areas are approximately selected by using Google Earth 2015 and village geographical data of Albania.
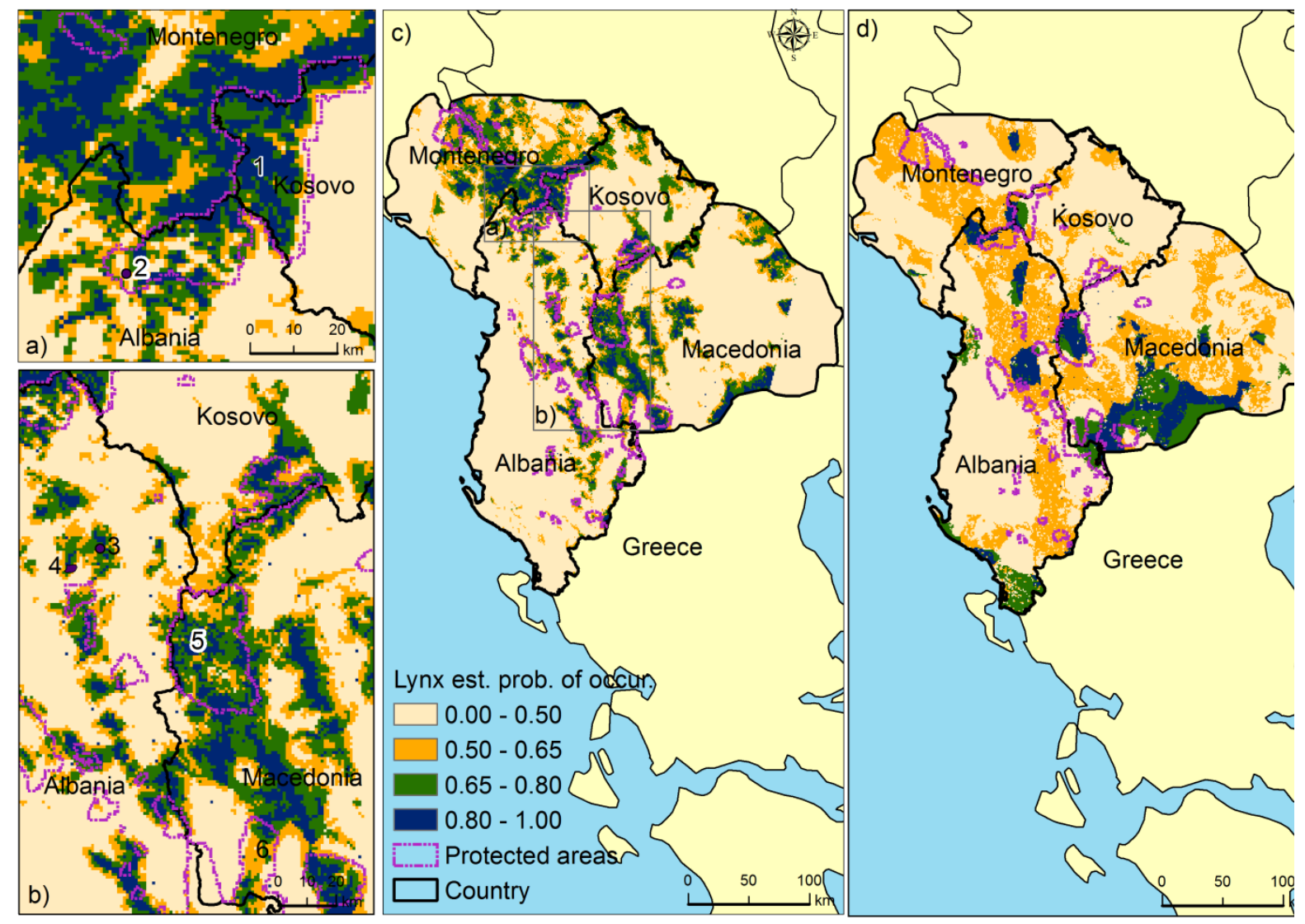
S12. Priority locations for extending current protected areas for the lynx conservation (with combined permanent + temporal occurrences, (a) the top 10 percent and 20 percent of the landscape for the lynx conservation as prioritized by Zonation constrained to the current protected areas (dashed lines), (b) result of unconstrained solution by Zonation

a)

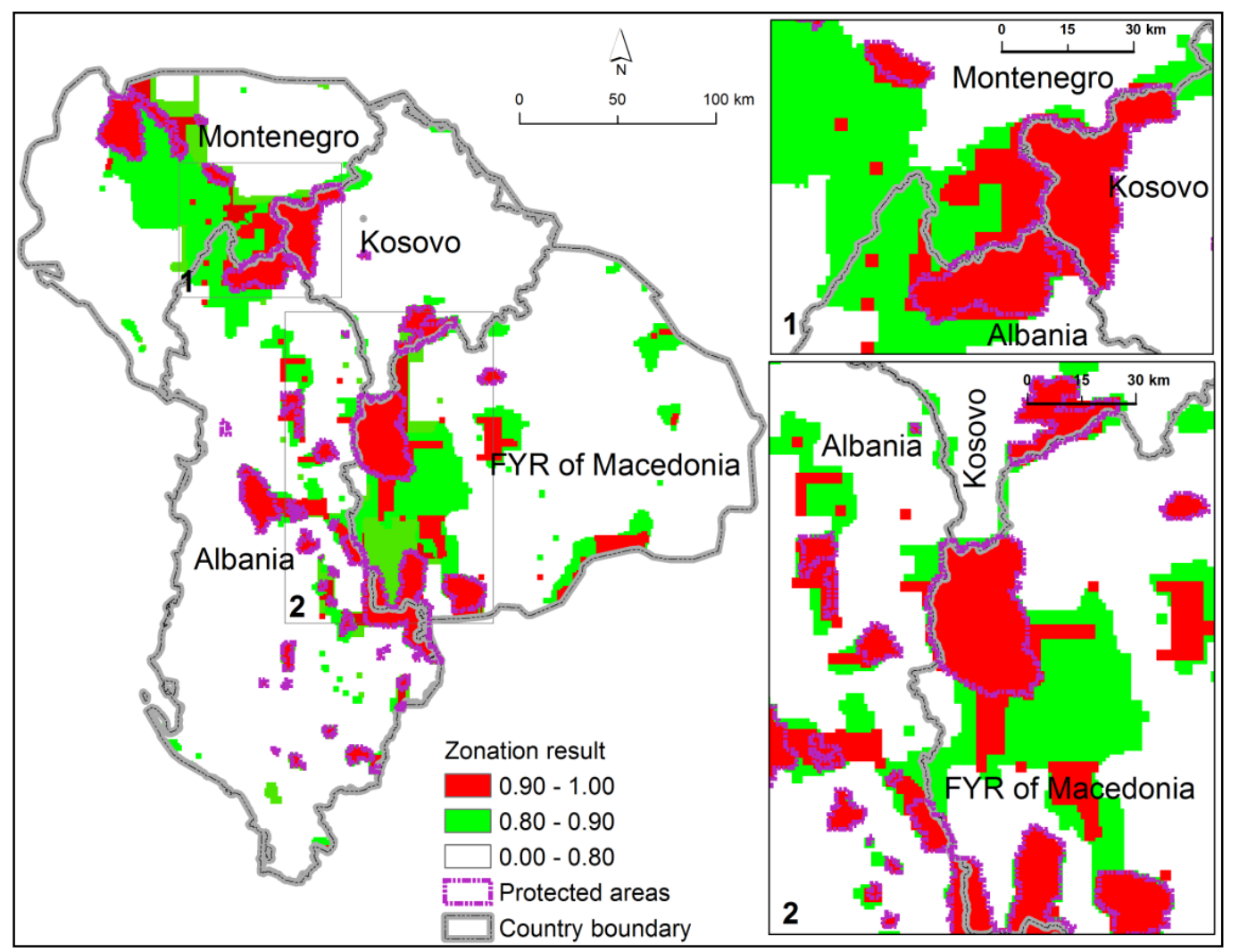

b)

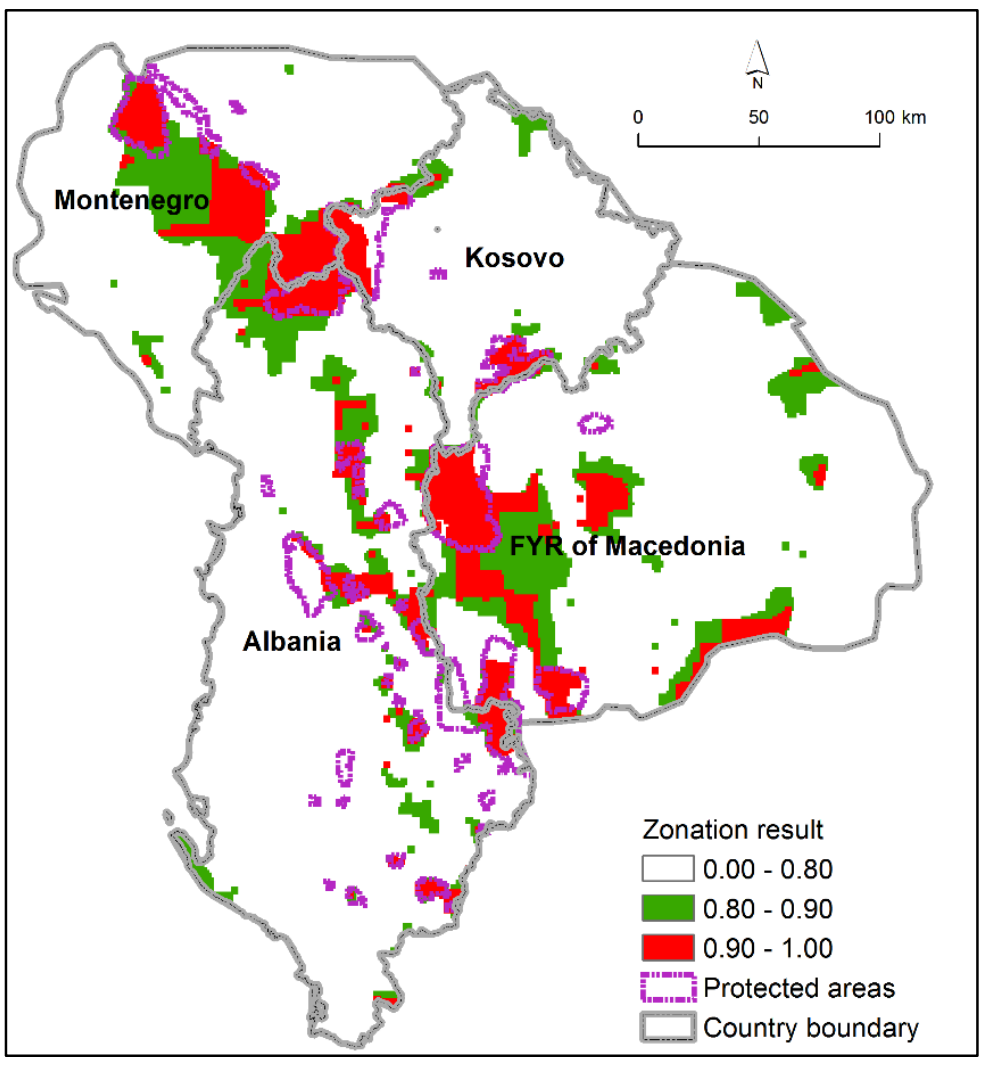




\section{S13. Stable forests in the cross-border areas}
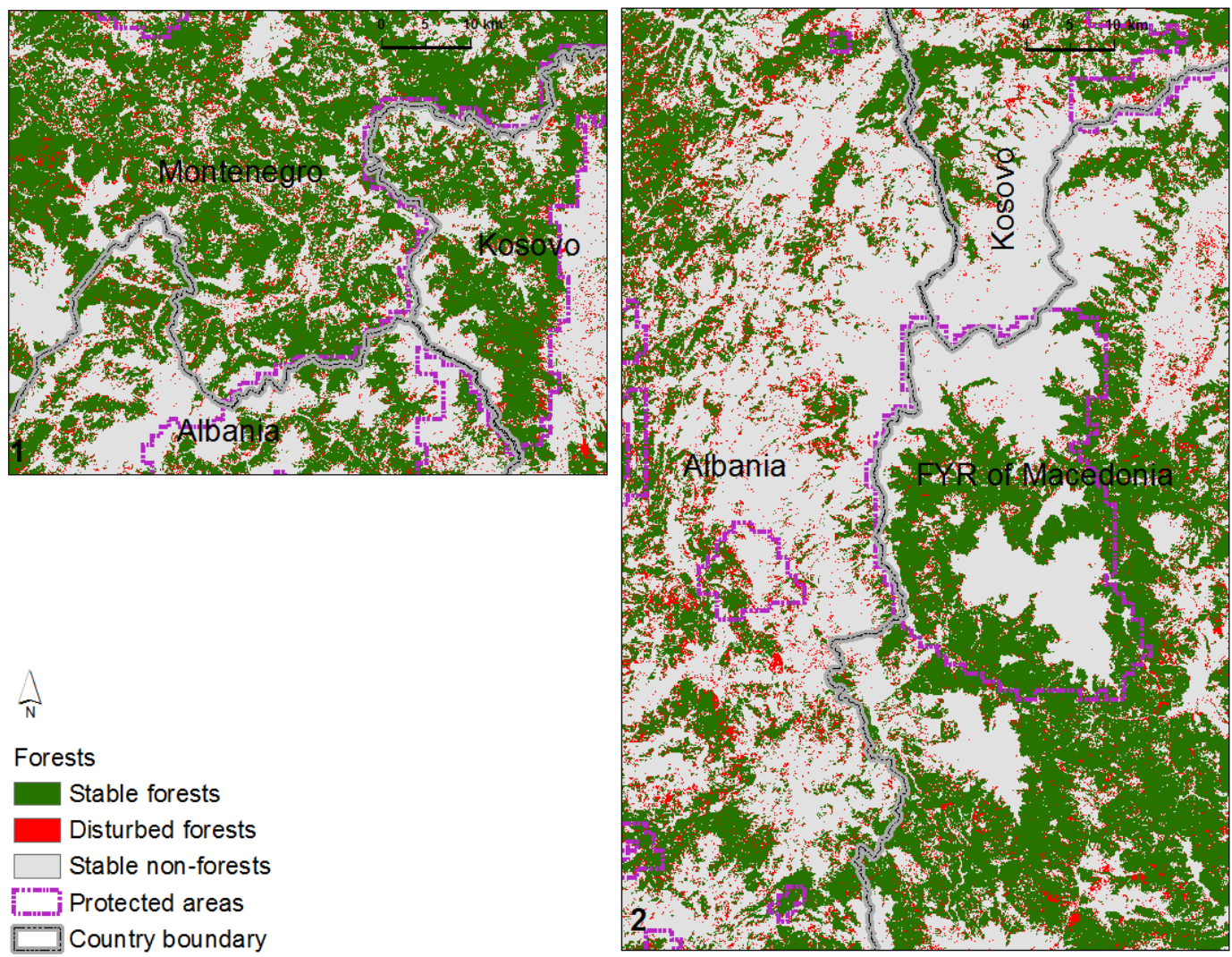

Figure S13. The changes of forest cover (disturbed forests) are observed from 2000 to 2007 consisting of forest decrease and increase. The decrease of forest cover in this period are primary caused by (legal and illegal) logging activities (particularly in Albania) (Laze 2013). Forest cover has changed inside of protected areas, in their surroundings and in stable forests. The conservation of stable forests within protected areas and in their surroundings contribute to the conservation of the lynx. Source of forest data is Suess (2010). 


\section{References}

Arx, M. v., C. Breitenmoser-Wuersten, F. Zimmermann, and U. Breitenmoser. 2004. Status and conservation of the Eurasian lynx (Lynx Lynx) in Europe in 2001. KORA Bericht 19, Muri b. Bern. Pages 330. available at: http://www.catsg.org/balkanlynx/20_blx-compendium/home/index_en.htm, last access: 27 December 2015.

Balkan Lynx Strategy Group. 2008. Balkan Lynx Strategy Group. Strategy for the Conservation of the Balkan Lynx in Macedonia and Albania. Peshtani, MK, 3-4 June 2008. available at: www.catsg.org/balkanlynx. last access: 27 December 2015.

Breitenmoser, U., M. v. Arx, F. Bego, G. Ivanov, E. Keçi, D. Melovski, G. Schwaderer, A. Stojanov, A. Spangenberg, A. Trajçe, and J. D. C. Linnell. 2008. Strategic planning for the conservation of the Balkan lynx. Proceedings of the III Congress of Ecologists of the Republic of Macedonia with International Participation, 06-09.10.2007, Struga Special issues of Macedonian Ecological Society. www.catsg.org/balkanlynx. 8. last access: 27 December 2015.

Chefaoui, R. M., and J. M. Lobo. 2008. Assessing the effects of pseudo-absences on predictive distribution model performance. Ecological modelling 210:478-486.

Environmental Systems Research Institute. 2014. The World. http://www.esri.com, last access: 24 October 2014.

European Environmental Agency. 2011. Corine land cover 2000 and 2006 by country. http://www.eea.europa.eu/data-and-maps, last access: 7 October 2015.

Fernández, N., D. Miguel, and P. Francisco. 2006. Landscape evaluation in conservation: molecular sampling and habitat modeling for the Iberian Lynx. Ecological Applications 2006:1037-1049.

Fernández, N., D. Miguel, P. Francisco, and M. David. 2003. Identifying breeding habitat for the Iberian Lynx: Inferences from a fine-scale spatial analysis. Ecological Applications 13:1310-1324.

Huang, C., L. Davis, and J. Townshend. 2002. An assessment of support vector machines for land cover classification International Journal of Remote Sensing 23:725-749.

Institute of Statistics Albania. 2011. Preliminary results of Population and Housing Census 2011. http://census.al, last access: 23 February 2014

IUCN. 2011. Institutional Support to the management of Protected Areas in Albania. Project description. http://www.iucn.org/about/union/secretariat/offices/europe/about/places/belgrade/projects/?8591/Instit utional-Support-to-the-management-of-Protected-Areas-in-Albania, last access: 11 May 2015

IUCN. 2012. Joint planning for protected areas. News story. http://cmsdata.iucn.org/downloads/system_components_for_two_areas_scheme.pdf, last access: 11 May 2015.

IUCN. 2013. Challenges for protected areas in Albania. Article. http://iucn.org/about/union/secretariat/offices/europe/?11820/Challenges-for-protected-areas-inAlbania, last access: 11 May 2015.

Ivanov, G., A. Stojanov, D. Melovski, V. Avukatov, E. Keçi, A. Trajçe, K. Mersini, O. Qazimi, F. Bego, G. Schwaderer, A. Spangenberg, J. Linnell, U. Breitenmoser, and M. v. Arx. 2008. Conservation status of 
the critically endangered Balkan Lynx in Albania and Macedonia. www.catsg.org/balkanlynx, last accessed: 27 December 2015.

Kanagaraj, R., T. Wiegand, S. Kramer-Schadt, M. Anwar, and S. P. Goyal. 2011. Assessing habitat suitability for tiger in the fragmented Terai Arc Landscape of India and Nepal. Ecography 34:970-981.

Knorn, J., A. Rabe, V. Radeloff, T. Kuemmerle, J. Kozak, and P. Hostert. 2009. Land cover mapping of large areas using chain classification of neighboring Landsat satellite images Remote Sensing of Environment 113:957-964.

Kramer-Schadt, S., E. Revilla, and T. Wiegand. 2005. Lynx reintroductions in fragmented landscapes of Germany: Projects with a future or misunderstood wildlife conservation? Biological conservation 125:169-182.

Kramer-Schadt, S., E. Revilla, T. Wiegand, and U. Breitenmoser. 2004. Fragmented landscapes, road moratlity and patch connectivity: modelling influences on the dispersal of Eurasian lynx. Journal of Applied Ecology 41.

Kuemmerle, T., O. Chaskovskyy, J. Knorn, V. C. Radeloff, I. Kruhlov, W. S. Keeton, and P. Hostert. 2009. Forest cover change and illegal logging in the Ukrainian Carpathians in the transition period from 1988 to 2007 Remote Sensing of Environment RSE-07342:14.

Laze, K. 2013. Identifying and understanding the patterns of forest cover change in Albania and Kosovo. 1st International Scientific Forum, ISF 2013, 12-14 December 2013, Tirana, Albania. European Scientific Institute. Vol. 2:pg. 128-151. ISBN: 978-608-4642-4616-4649. http://isforum.us/index.php/proceedings.

Laze, K. 2014. Identifying and understanding the patterns and processes of forest cover change in Albania and Kosovo in Studies on the Agricultural and Food Sector in Transition Economies. Leibniz Institute of Agricultural Development in Transition Economies (IAMO). Vol. 74. ISBN 978-3-938584-78-1, Halle (Saale).

May, R., J. v. Dijk, P. Wabakken, J. E. Swenson, D. C. L. John, B. Zimmermann, J. Odden, H. C. Pedersen, R. Andersen, and A. Landa. 2008. Habitat differentation within the large-carnivore community of Norway's multiple-use landscapes. Journal of Applied Ecology 45:1382-1391.

METI, and NASA. 2011. The Ministry of Economy, Trade, and Industry (METI) of Japan, the United States National Aeronautics and Space Administration (NASA). Advanced Spaceborne Thermal Emission and Reflection Radiometer. ASTER Global Digital Elevation Map. http://asterweb.jpl.nasa, last access: 24 October 2014.

Naves, J., T. Wiegand, Eloy Revilla, and M. Delibes. 2003. Endangered species constrained by natural and human factors: the case of Brown Bears in Northern Spain. Conservation biology 17:1276-1289.

Schadt, S., E. Revilla, T. Wiegand, F. Knauer, P. Kaczensky, U. Breitenmoser, L. Bufka, J. Červený, P. Kouber, T. Huber, C. Staniša, and L. Trepl. 2002. Assessing the suitability of central European landscapes for the reintroduction of Eurasian lynx. Journal of Applied Ecology 39:189-203.

Schwaderer, G., A. Spangenberg, D. Melovski, A. Trajçe, and F. Bego. 2008. Protected areas in species conservation - the protected area component within the frame of the Balkan lynx recovery programme. Proceedings of the III Congress of Ecologists of the Republic of Macedonia. Special issues of Macedonian Ecological Society. Skopje. Vol. 8:265-269. 
State Statistical Office Macedonia. 2010. Macedonia in Figures 2010. http://makstat.stat.gov.mk/english, last access: 23 February 2014

Statistical Office of Kosovo. 2011. Preliminary results of the Kosovo 2011 population and housing census. http://esk.rks-gov.net/rekos2011, last access: 23 February 2014.

Statistical Office of Montenegro. 2011. The census of Population, Households, and Dwellings 2011. http:// www.monstat.org/eng, last access: 23 February 2014.

Suess, S. 2010. Forest cover change of post-socialist landscapes in Albania and Kosovo: A remote sensing and statistical approach. Diplomarbeit. Universität Humboldt zu Berlin. Germany.

Wiegand, T., J. Naves, M. F. Garbulsky, and N. Fernández. 2008. Animal habitat quality and ecosystem functioning: exploring seasonal patterns using NDVI. Ecological Applications 78:87-103. 